\title{
Shale gas: a life-cycle perspective for UK production
}

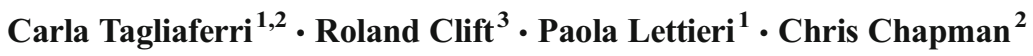

Received: 14 October 2015 / Accepted: 12 September 2016

(C) The Author(s) 2016. This article is published with open access at Springerlink.com

\begin{abstract}
Purpose Following the boom of shale gas production in the USA and the decrease in the US gas prices, increasing interest in shale gas is developing in many countries holding shale reserves and exploration is already taking place in some EU countries, including the UK. Any commercial development of shale gas in Europe requires a broad environmental assessment, recognizing the different European conditions and legislations.

Methods This study focuses on the UK situation and estimates the environmental impacts of shale gas using lifecycle assessment (LCA); the burdens of shale gas production in the UK are compared with the burdens of the current UK natural gas mix. The main focus is on the analysis of water impacts, but a broad range of other impact categories are also considered. A sensitivity analysis is performed on the most environmentally criticized operations in shale gas production, including flowback disposal and emission control, by considering a range of possible process options.
\end{abstract}

Responsible editor: Shabbir Gheewala

Electronic supplementary material The online version of this article (doi:10.1007/s11367-016-1207-5) contains supplementary material, which is available to authorized users.

Paola Lettieri

p.lettieri@ucl.ac.uk

1 Chemical Engineering Department, University College London, Torrington Place, London WC1E 7JE, UK

2 Advanced Plasma Power (APP), Unit B2, Marston Gate, South Marston Business Park, Swindon SN3 4DE, UK

3 Centre for Environmental Strategy, The University of Surrey, Guildford, Surrey GU2 7XH, UK
Results and discussion Improper waste water management and direct disposal or spills of waste water to river can lead to high water and human ecotoxicity. Mining of the sand and withdrawal of the water used in fracking fluids determine the main impacts on water use and degradation. However, the water degradation of the conventional natural gas supply to the UK is shown to be even higher than that of shale gas. For the global warming potential (GWP), the handling methods of the emissions associated with the hydraulic fracturing influence the results only when emissions are vented. Finally, the estimated ultimate recovery of the well has the greatest impact on the results as well as the flowback ratio and flowback disposal method.

Conclusions This paper provides insights to better understand the future development of shale gas in the UK. Adequate waste water management and emission handling significantly reduce the environmental impacts of shale gas production. Policy makers should consider that shale gas at the same time increases the water consumption and decreases the water degradation when compared with the gas mix supply. Furthermore, the environmental impacts of shale gas should be considered according to the low productivity that force the drilling and exploitation of a high number of wells.

Keywords Life-cycle assessment · UK fracking - UK shale gas exploitation - Water life cycle of shale gas

\section{Introduction}

The first shale well was drilled in 1821 in Fredonia (New York, USA) with the gas used for town lighting (GWPC and ALL Consulting 2009). However, the low productivity of shale wells delayed large-scale development of shale gas until the 1970 s and 1980 s when the development of new 
technologies made the production of shale gas cost-effective (Wang and Krupnick 2013). During the 2000s, shale gas exploitation has seen a rapid growth: shale gas accounted only for $1.6 \%$ of total US gas production in 2000 , but by 2013 , this value had increased to $34 \%$, and it is expected that nearly half of US production will be supplied by shale gas extraction by 2035 (Vengosh et al. 2014).

Following the boom of shale gas production in the USA and the decrease in the US gas prices, increasing interest in shale gas is developing in many countries holding shale reserves. Many European countries, including for example the UK, France and Poland are reported to hold recoverable resources of shale gas (EIA 2013). None of them has currently started commercial drilling operations, but exploration is taking place in the UK, Poland, Germany, Romania, Denmark and Hungary (Shale Gas Europe 2014).

At the same time, controversies have arisen over whether European shale gas exploitation could parallel that in the USA (Boersma 2013; Oil and Gas 2013). Major concerns have been voiced about different European conditions compared with the USA: different geology, higher population density, different laws governing land ownership and lack of relevant drilling expertise and infrastructure.

Hence, the picture of a possible new global market that includes the production of shale gas in different parts of the world is not clear. A potential shift of emissions between fossil and renewable energy sectors has also to be identified. Some of the potential implications between shale gas development, global warming, policy and economics are reported in Newell and Raimi (2014); it is clear that the global economic debate on shale gas development needs to be rooted on solid knowledge about its environmental impacts. Concerns about the environmental burdens of drilling and production of shale gas coupled with a strong nuclear lobby have pushed some countries such as France to ban exploration and trials (Cooper et al. 2014). Hence, it is of major importance to identify the possible sources of pollution and to gain more insight into the environmental impact of shale gas production. A rigorous assessment in the European context requires contextualizing future studies on shale gas extraction to EU conditions (policies, geological shale formation, technologies used etc.). This is addressed in our study.

\subsection{An overview on the shale gas extraction process}

Geophysical locations and the extraction process differentiate conventional and unconventional natural gas (Peduzzi and Harding 2013). Unconventional gas is trapped in formation characterized by a very low permeability $\left(10^{-9}\right.$ Darcy for unconventional shale formation versus $10^{-2}$ Darcy for conventional sandstones (Amann-Hildenbrand et al. 2012; DECC 2013a)), such as shale, tight sands and coal beds (Broadhead 2012). The entire process of shale gas extraction and production involves the following operations: site exploration and preparation, road and well pad construction, vertical and then horizontal drilling, well casing, perforation, hydraulic fracturing, completion, production and abandonment and reclamation of the site (Skea 2015).

Strata containing shale gas can be very thin (Rozell and Reaven 2012) so efficient extraction is achieved through a combination of vertical drilling, to reach the shale formation to a depth of approximately $1500 \mathrm{~m}$, and then directional drilling, to follow the shale formation for a horizontal section of at least $1500 \mathrm{~m}$ (Broderick et al. 2011). Steel casing pipes are installed in the borehole and cemented to protect the surrounding rocks, improve well's integrity (Cooper et al. 2014) and prevent leakage of natural gas through the well bore during the production phase.

The casing of the horizontal well is then perforated using perforating guns (The Museum of Earth 2012) and hydraulic fracturing is carried out. Fracturing fluids are pumped into the well at high pressure to create fractures in the rock from the horizontal bore (Wood et al. 2011) that can extend a few hundred meters vertically. The fracturing fluid comprises almost $99 \%$ of water and proppant (Cuadrilla 2016) and a blend of different chemicals. The proppant (usually silica sand) holds the rock fractures open during gas production; conversely, the chemicals enhance the characterization and performance of fracturing fluid (Clark et al. 2013a), for instance, preventing growth of organism, increasing stability and reducing friction.

Flowback water is the water produced from the well immediately after the well is depressurized and before gas production commences. The flowback ratio (ratio of flowback fluid to fracturing fluid) varies between different plays, but it is usually between 20 and $80 \%$. However, for some plays in the USA, it is reported to be even higher than $100 \%$ (Clark et al. 2011). The volume of flowback water reduces over time and its composition converges towards that of brine naturally present in conventional and unconventional formations.

The process of well completion includes preparation of the borehole, installation of pipes, escape of gas to clear the debris and, for shale plays, also the flowback period just described.

During the life of conventional and shale gas wells workovers and unloading also occur. Workovers involve periodical cleaning, replacement of production pipes and for shale gas wells, also re-fracturing. Conversely, the unloading operations involve clearing the liquids that build up and may block gas flow through the well. Following production, both conventional and shale gas are processed and passed into a main transport pipeline.

The initial production rate of shale gas wells is highly variable between different wells (O'Sullivan and Paltsev 2012), but it decreases very rapidly; for example Speight (2009) estimates that half the production of a shale well occurs within 5 years while O'Sullivan and Paltsev (2012) report that shale well output tends to drop by $60 \%$ or more over the first year of 
production. However, productivity and its decline are more moderate during the following years of well life. For these reasons, shale wells are commonly re-fractured to restore gas production. The amount of gas expected from a well during its entire life is defined as the estimated ultimate recovery (EUR).

\subsection{Environmental impacts of shale gas}

The rapid spread of the hydraulic fracturing for shale gas production in 2010 led to a sharp increase in research activity focussing on the carbon footprint of this new technology, with US research groups leading the work in this field (Skone et al. 2011; Stephenson et al. 2011; Howarth et al. 2011b; Jiang et al. 2011).

Howarth et al. (2011a) were among the first authors to estimate the global warming potential of US shale; they made the highly contested observation (Burnham et al. 2011; Hultman et al. 2011; Howarth et al. 2012a, b; Cathles et al. 2012) that shale gas may deliver an even higher carbon footprint than coal; this was however based on high estimates for fugitive emissions, using a high global warming potential (GWP; at 20 years time horizon) for methane and comparing the results per megajoule of energy contained within the fuel as opposed to kilowatt of electricity generated, thereby ignoring the higher average efficiency of gas compared with coalfired power plants.

Conversely, Stephenson et al. (2011), Burnham et al. (2011), Jiang et al. (2011), O'Sullivan (2012), Weber and Clavin (2012), Laurenzi and Jersey (2013) and Dale et al. (2013) reported that the emissions due to shale gas production and use do not significantly differ from those of conventional gas and are significantly lower than the emissions from electricity production from coal. For example Hultman et al. (2011) estimated the GHG impact of shale gas to be $11 \%$ higher than that of conventional gas production but only $56 \%$ that of coal. More recently, Pacsi et al. (2013) and Allen et al. (2015a, b) evaluated the greenhouse gas emissions from shale gas on the basis of experimental measurements at well sites, and Newell and Raimi (2014) examined how the lower prices of natural gas due to shale gas development in the USA might affect the national greenhouse gas emissions.

The environmental impacts of shale gas have been the focus of some studies also outside the USA, in countries that might develop shale gas production (such as (Chang et al. 2014, 5) in China).

In the UK, Wood et al. (2011); DECC (2013a, b) have calculated the carbon footprint of shale gas extraction; however, their inventory data relies mainly on US estimates.

The main focus of all the studies previously mentioned is the estimation of the emissions and the associated carbon footprint of shale gas production and use. Very few studies explore also other impacts: the water life cycle of shale gas extraction is analysed by Clark et al. (2013b) and Jiang et al. (2014) in the USA and Tagliaferri et al. (2015) in the UK. The latter was a preliminary study by the same authors of this paper that however was very limited in scope as it did not consider different procedures for shale gas production nor the comparison with the gas grid mix.

In the UK, Stamford and Azapagic (2014) and Cooper et al. (2014) are the only ones so far who have analysed different impact indicators (i.e. depletion of energy sources, acidification potential etc., but no water impacts) in addition to the carbon footprint. They both compared the environmental burdens of the electricity production from shale gas with the electricity production from other sources including coal, nuclear, wind and solar, hydro and biomass. Therefore, they considered the role that shale gas may play in affecting the impacts from electricity generation in the UK. This perspective refers to a particular use of natural gas (electricity production) which currently represents only $30 \%$ of the total electricity generated in the UK.

This paper, differently from previously published work in the UK, specifically adopts a natural gas production perspective and does not consider the final use of natural gas for electricity generation. This perspective has been chosen to reflect the current and future major use of natural gas in the UK that is heat and not electricity production. This study reports a comprehensive attributional life-cycle assessment and hot-spot analysis of shale gas production and distribution in the UK, considering the current EU exploration and development of shale gas. This paper stems from the previous paper by the same authors, but it significantly expands the analysis on water impacts which is the main contribution of the current work. We focus on the analysis of water consumption, degradation and use of shale gas production within the UK context and also on the comparison with the grid mix. In addition, this work considers a broad range of environmental impacts, including acidification potential, abiotic depletion fossil, toxicities, etc., hence, providing a further reference point against previous works.

The LCA model is based on the analysis of literature data from more than 60 publicly available sources. The robustness of the model is checked through sensitivity analysis on key parameters. The system boundary excludes the use of natural gas, as this would be identical whether shale gas or conventional gas is used.

\section{Methods}

\subsection{Modelling assumptions and system boundary}

The modelling approach and the system boundary are shown in Fig. 1, and the main inventory data are reported in Table 1 (more details on data source and assumptions of the operations 


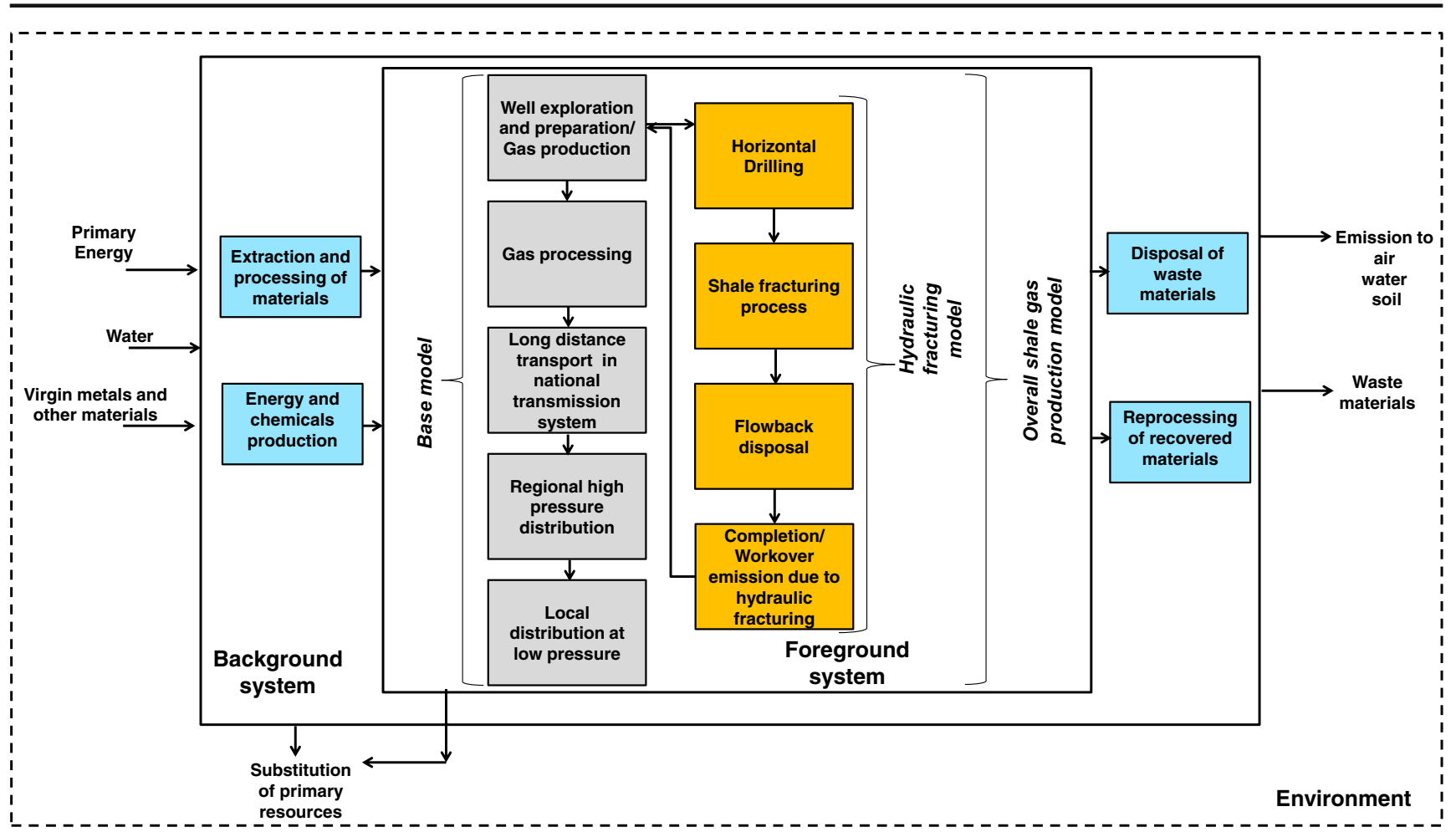

Fig. 1 System boundary. Yellow boxes represent the hydraulic fracturing model; grey boxes identify the base model; and the blue boxes refer to the activities of the background system

identified in Fig. 1 are reported in the Electronic supplementary material). The entire life cycle of shale gas production process has been considered in the modelling approach. This includes the indirect activities of energy, chemicals and water production and recovery and final disposal of waste material identified in the background of Fig. 1 . The background system exchanges energy and material with foreground system. This includes the entire supply chain of shale gas production, processing and distribution to the final consumer at low pressure. Avoided burdens have also been considered for the production of valuable hydrocarbon byproducts other than natural gas.

The following stages were considered:

1. Well site exploration and investigation.

2. Well pad and road preparation and construction.

3. Well vertical drilling. Production of materials needed for drilling; transport of materials; energy required during drilling and emissions from machinery; emissions during drilling; casing and cementing; disposal of drilling wastes.

4. Hydraulic fracturing of the well. Horizontal drilling; production and transport of water, chemicals and sand needed for fracturing; energy used during the hydraulic fracturing and emissions from machinery; disposal of wastes.

5. Well completion. Energy and materials required; disposal of flowback and produced water from the well; emissions of natural gas during well completion, workovers, unloadings; re-fracturing.
6. Production. Processing and cleaning.

7. Pipe construction and transmission.

8. Post production phase. Decommissioning, plugging and removing of equipment.

As widely reported in literature (Stephenson et al. 2011; Weber and Clavin 2012; Stamford and Azapagic 2014), it is assumed that extraction, processing and distribution of shale gas involve exactly the same processes as onshore extraction of conventional gas, but operations associated with hydraulic fracturing must be added. Therefore, two models have been built: the first (identified as the common operations model) accounts for the extraction of conventional gas and includes all the common processes between conventional and unconventional extraction: gas field exploration, natural gas production, purification, long distance transport and regional distribution. The second model (identified as the hydraulic fracturing model) includes all the processes specific to shale gas: horizontal drilling, fracking of the shale rocks, flowback disposal and handling of emissions associated with hydraulic fracturing. The emissions in the hydraulic fracturing model represent the difference in emissions between production of shale gas and conventional gas.

The two models are integrated and hence the total environmental burdens of shale gas extraction, processing, transport and distribution are calculated. The model for conventional onshore gas - common operations model-relies on data from Ecoinvent database version 3.1 (Swiss Centre for Life 
Table 1 Key inventory data reported per MJ LHV of processed natural gas (S.0)
Water for hydraulic fracturing

Sand for fracturing (silica, quarts sand)

$\mathrm{kg}$

$7.25 \mathrm{E}-04$

Additives offracking fluids

Acid: hydrochloric acid or muriatic acid

Friction reducer: petroleum distillate

Surfactant: isopropanol

Cly stabilizer/controler: potassium chloride

Geling agent; guar gum or hydroxyethyl cellulose

Scale inhibitor: ethylene glycol

PH-adjusting agent: sodium bicarbonate and sodium potassium hydroxide

Breaker: ammonium persulfate

Crosslinker: borate salts

Iron control: citric acid

Bactericide/biocide: glutaraldehyde

Corrosion inhibitor: formamide

Flowback disposed to industrial treatment

Energy requirements for the freeze-thaw evaporation process

Energy requirements for pumping the hydraulic fracturing fluids in the well

Diesel

Emissions for pumping the hydraulic fracturing fluids in the well

$\mathrm{CO}_{2}$

$\mathrm{SO}_{2}$

Nox

PM

$\mathrm{CO}$

NMVOC

Materials used for horizontal drilling

Steel

Portland cement

Gilsonite (asphaltite)

Diesel fuel

Bentonite

Soda ash

Gelex

$\mathrm{m}^{3}$

$5.46 \mathrm{E}-06$

$\mathrm{kg}$

$\mathrm{kg}$

$\mathrm{kg}$

$\mathrm{kg}$

$\mathrm{kg}$

$\mathrm{kg}$

$\mathrm{kg}$

$\mathrm{kg}$

$\mathrm{kg}$

$\mathrm{kg}$

$\mathrm{kg}$

$\mathrm{kg}$

$\mathrm{kg}$

$\mathrm{kWh}$

$\mathrm{kg}$

$2.26 \mathrm{E}-05$

$5.36 \mathrm{E}-07$

$5.36 \mathrm{E}-07$

$2.01 \mathrm{E}-07$

$5.36 \mathrm{E}-08$

$5.36 \mathrm{E}-08$

$1.55 \mathrm{E}-03$

$1.96 \mathrm{E}-05$$$
1.96 \mathrm{E}-05
$$

$\mathrm{kg}$

7.19E-05

$\mathrm{kg}$

$3.68 \mathrm{E}-05$

$\mathrm{kg} \quad 5.57 \mathrm{E}-05$

$\mathrm{kg}-2.10 \mathrm{E}$

$-06$

kg $\quad 4.29 \mathrm{E}-05$

$\mathrm{kg} \quad 1.03 \mathrm{E}-05$

Stephenson et al. (2011), Burnham et al. (2011), Jiang et al. (2011), Weber and Clavin (2012), Laurenzi and Jersey (2013), Dale et al. (2013), Stamford and Azapagic (2014),

Jackson et al. (2015)

Burnham et al. (2011), Jiang et al. (2011), DECC (2013b), Laurenzi and Jersey (2013), Dale et al. (2013), Stamford and Azapagic (2014)

Jiang et al. (2011)

\section{Stephenson et al. (2011), Thinkstep (2015)}

Stephenson et al. (2011)

Howarth et al. (2011a), Lechtenbohmer et al. (2011)

$\mathrm{kg} \quad 7.29 \mathrm{E}-08$

$\mathrm{kg} \quad 1.01 \mathrm{E}-06$

$\mathrm{kg} \quad 8.39 \mathrm{E}-08$

$\mathrm{kg} \quad 2.18 \mathrm{E}-07$

$\mathrm{kg} \quad 3.17 \mathrm{E}-09$

$\mathrm{kg} \quad 1.72 \mathrm{E}-07$

$\mathrm{kg} \quad 1.25 \mathrm{E}-09$
Clark et al. (2011), Burnham et al. (2011), Burnham et al. (2013), Stamford and Azapagic (2014) 
Table 1 (continued)

\begin{tabular}{|c|c|c|c|}
\hline Polypac & $\mathrm{kg}$ & $3.24 \mathrm{E}-07$ & \\
\hline Xanthum gum & $\mathrm{kg}$ & $1.64 \mathrm{E}-07$ & \\
\hline Water throughput & $\mathrm{kg}$ & $1.80 \mathrm{E}-07$ & \\
\hline $\begin{array}{l}\text { Emission due to horizontal } \\
\text { drilling }\end{array}$ & & & $\begin{array}{l}\text { Howarth et al. (2011a), Lechtenbohmer et al. } \\
\text { (2011) }\end{array}$ \\
\hline $\mathrm{CO}_{2}$ & $\mathrm{~kg}$ & $1.36 \mathrm{E}-04$ & \\
\hline $\mathrm{SO}_{2}$ & $\mathrm{~kg}$ & $1.38 \mathrm{E}-07$ & \\
\hline Nox & $\mathrm{kg}$ & $1.91 \mathrm{E}-06$ & \\
\hline $\mathrm{PM}$ & $\mathrm{kg}$ & $1.59 \mathrm{E}-07$ & \\
\hline $\mathrm{CO}$ & $\mathrm{kg}$ & $4.13 \mathrm{E}-07$ & \\
\hline NMVOC & $\mathrm{kg}$ & $6.01 \mathrm{E}-09$ & \\
\hline $\begin{array}{l}\text { Potential emission due to well } \\
\text { completation and workover } \\
\text { allocated to the hydraulic } \\
\text { fracturing model-those } \\
\text { emissions have been further } \\
\text { modified to account for REC }\end{array}$ & & & $\begin{array}{l}\text { Burnham et al. (2013), Kang et al. (2014), } \\
\text { Allen et al. (2015a, b) }\end{array}$ \\
\hline $\mathrm{CH}_{4}$ & $\mathrm{~g} \mathrm{CH}_{4}$ & $5.40 \mathrm{E}-02$ & \\
\hline $\mathrm{CO}_{2}$ & $\mathrm{~g} \mathrm{CO}_{2}$ & $5.18 \mathrm{E}-03$ & \\
\hline $\mathrm{C}_{2} \mathrm{H}_{6}$ & $\begin{array}{l}\mathrm{g} \\
\mathrm{C}_{2} \mathrm{H}_{6}\end{array}$ & $3.54 \mathrm{E}-03$ & \\
\hline $\mathrm{C}_{3} \mathrm{H}_{8}$ & $\begin{array}{l}\mathrm{g} \\
\mathrm{C}_{3} \mathrm{H}_{8}\end{array}$ & $1.73 \mathrm{E}-03$ & \\
\hline $\mathrm{N}_{2}$ & $\mathrm{~g} \mathrm{~N}_{2}$ & $7.70 \mathrm{E}-03$ & \\
\hline
\end{tabular}

Cycle Inventories 2014), whereas the hydraulic fracturing model is entirely based on literature data (for key data see Table 1, Table S13 in the Electronic supplementary material). All indirect, direct and avoided burdens considered in the LCA model are UK specific. Very few inventory data, such as composition of the flowback water for the UK, were not publicly available in literature because of the early stage development of the shale gas exploitation in the UK. Hence, as reported in the Electronic supplementary material, for these cases, values for the USA were adapted to the UK case. Goods transport is also included in the system boundaries. GaBi software version 6.110 (Thinkstep 2015) was used to model the LCA scenarios.

The shale gas burdens are compared with the current UK gas grid mix. The latter has also been modelled in Gabi software using the Ecoinvent database version 3.1 (Swiss Centre for Life Cycle Inventories 2014).

The functional unit of this work is the delivery of $1 \mathrm{MJ}$ LHV of natural gas to the final consumer at low pressure ( $<7$ bar and $>0.75$ mbar gauge). All results are reported according to the functional unit.

\subsection{Scenarios}

The process of shale gas extraction using hydraulic fracturing is still in the development stage in terms of both technology and regulation in the UK. Industry data is therefore rarely publicly disclosed and field measurements are lacking so that the limited inventory data available are widely contested (Laurenzi and Jersey 2013; Dale et al. 2013). A sensitivity analysis on key parameters is therefore important and in this paper it is performed according to the literature, as here reported.

Some authors (Burnham et al. 2011; Jiang et al. 2011; Weber and Clavin 2012; O'Sullivan and Paltsev 2012) report that the amount of emissions and the emissions handling method are the most important parameters influencing the uncertainty in the carbon footprint of shale gas. Conversely, others (Laurenzi and Jersey 2013) have concluded that the Estimated Ultimate Recovery (EUR) is the parameter that most influences the results.

Few authors have critically reviewed the potential risks that shale gas operation and mainly flowback disposal pose to the water source (Vengosh et al. 2014) and water life cycle, hence analysing different key parameters such as flowback ratio, flowback recycled fraction, the amount of water used according to different shale plays (Clark et al. 2013c; Jiang et al. 2014) and wastewater composition (Maguire-Boyle and Barron 2014).

In this paper, the sensitivity analysis explores 18 scenarios (S.) and 5 key parameters as reported in Table 2:

S.O (base scenario). This represents the best option regarding the emission handling method and flowback water disposal. Emissions are assumed to be completely captured and gathered into the pipeline as also in Weber and Clavin (2012). Flowback is assumed to be completely disposed through adequate industrial treatment and the fraction of flowback is assumed to be $25 \%$ as largely reported in literature (Boschee 2014). The estimate 


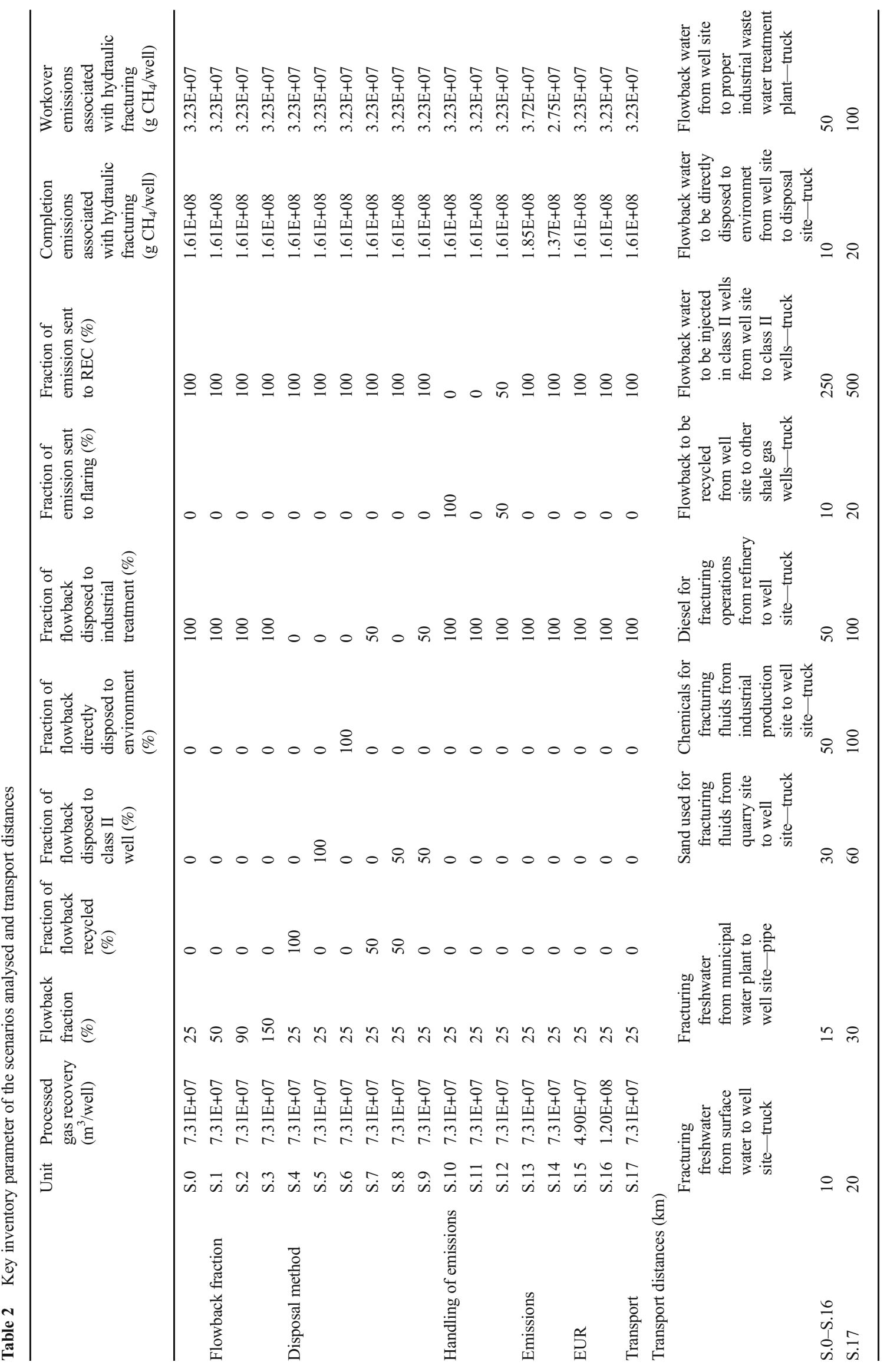


ultimate recovery is 85 million $\mathrm{m}^{3}$ (DECC 2013b; Stamford and Azapagic 2014).

Scenarios 1-3 explore different flowback fractions. All the assumptions are the same as in the base scenario except for the flowback fraction that varies between 25 and $150 \%$ as also reported in literature (Clark et al. 2011; Burnham et al. 2013).

Scenarios 4-9 analyse different flowback disposal methods (according to (Jiang et al. 2014)) including $100 \%$ direct disposal to environment, $100 \%$ recycling and $100 \%$ disposal to class II wells. Combinations of the different methods are also explored. Avoided burdens are allocated to the flowback recycling as this avoids the exploitation of new resources for the fracturing of new wells.

Scenarios 10-12 analyse different handling methods of the emissions from completion and workover due to the process of hydraulic fracturing; $100 \%$ flaring and $100 \%$ venting are analysed, as well as $50 \%$ flaring and $50 \%$ capturing. Although scenario 11 (100\% of the emissions are vented) does not represent a feasible option according to the UK regulation, it has nevertheless been explored to identify the potential threats of complete venting.

Scenarios 13-14 explore a $15 \%$ increase/decrease in the amount of completion/workover emissions due to the hydraulic fracturing process, in virtue of the current debate on this in the literature (Burnham et al. 2011; Howarth et al. 2011b; Jiang et al. 2011; Forster and Perks 2012; Cathles et al. 2012; Stephenson and Shaw 2013).

Scenario 15-16 investigate an increase/decrease of EUR according to the values reported in DECC (2013a, b).

Scenario 17 studies the effect of goods transport distances on the environmental burden of shale gas. In this scenario, all transport distances are doubled.

\subsection{Life-cycle impact assessment methodology}

The environmental impact results of this life-cycle study on shale gas production are calculated following the CML 2001 (Guinée 2002) Method characterization factors, version 4.5 (April 2015), which is based on the ISO standards (ISO 14040 2006).

The environmental concerns related to water scarcity due to population growth and economic development have been growing during the last decades (Kounina et al. 2012). This justifies a water-related approach in life-cycle inventories and assessments. In particular, water use is reported to be a critical issue in the operations required for shale gas extraction (Vengosh et al. 2014). Therefore, the impacts related to fresh water use, degradation and consumption are analysed separately according to the standard ISO 14046 (ISO 14046 2014).
Water use is the measured amount of water input into a product system or process (this usually is the total water withdrawal from the environment). Fresh water use is further differentiated in consumptive water use and degradative water use.

The freshwater consumption includes all fresh water losses on a watershed level which are caused by evaporation, release of fresh water into the sea (as fresh water is a limited natural resource) etc. The water consumption identifies the water losses associated with water use.

Degradative use takes place when the water used remains in the same watershed and the quality has been altered. Degradative use (water pollution, release of contaminants or heat into water bodies) describes changes in quality which are covered by specific impact categories of LCA (e.g. eutrophication, acidification, ecotoxicity, assessment of thermal emissions).

This work focuses at the same time on polluting impacts to fresh water (using the freshwater aquatic ecotoxicity potential) and on the assessment of water use (degradation and consumption).

Further description of the LCA methodology is reported in the Electronic supplementary material.

\section{Results and discussion}

In the following description, the figures numbered with $\mathrm{S}$ are reported in the Electronic supplementary material.

Water use The hydraulic fracturing process is the main contributor to the freshwater use of the overall shale gas model (it determines between 95 and $87 \%$ of the total water use for S. 15 and 16, respectively, see Fig. 2a; for water life cycle, see Fig. 3); the results are highly dependent on the EUR as shown for S.15 and S.16. S.3 and S.15 show the absolute highest water use because of the highest flowback ratio (and therefore the highest amount of fresh water needed to treat the flowback) and lowest EUR, respectively. S.4 and S.16 determine the lowest absolute water use because of the flowback recycling (that avoids new fresh water withdrawal) and the highest EUR, respectively.

The hot-spot analysis of the hydraulic fracturing model (see Fig. $2 b)$ shows that the fracking of shale formation and, depending on the scenario, also the flowback disposal process cause the highest impact on the water use. No parameter

Fig. 2 Water impacts of shale gas production and distribution. a Water use of the overall shale gas model. b Hot-spot analysis: water use of the hydraulic fracturing model. c Hot-spot analysis: water use of the hydraulic fracturing of shale formations. d Water consumption of the overall shale gas model. e Hot-spot analysis: water consumption of the hydraulic fracturing model. f FAETP of the overall shale gas model. $\mathbf{g}$ FAETP of the common operations model. The results are reported for the delivery of $1 \mathrm{MJ}$ LHV of natural gas to the final consumer 
a)

口UK grid mix

口Common operations model

口Hydraulic fracturing model

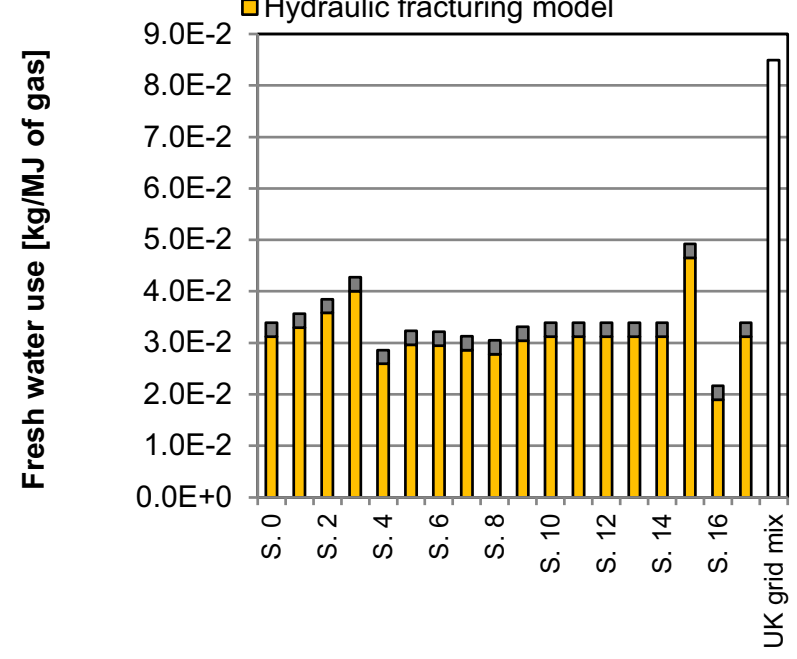

b)
- Emissions
口Flowback disposal
$\square$ Shale fracturing process
口Horizontal drilling

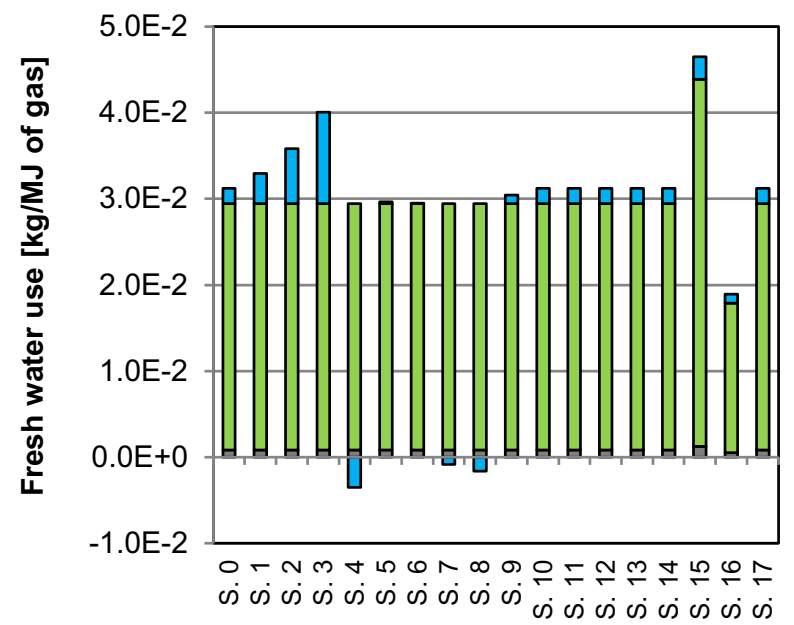

c)

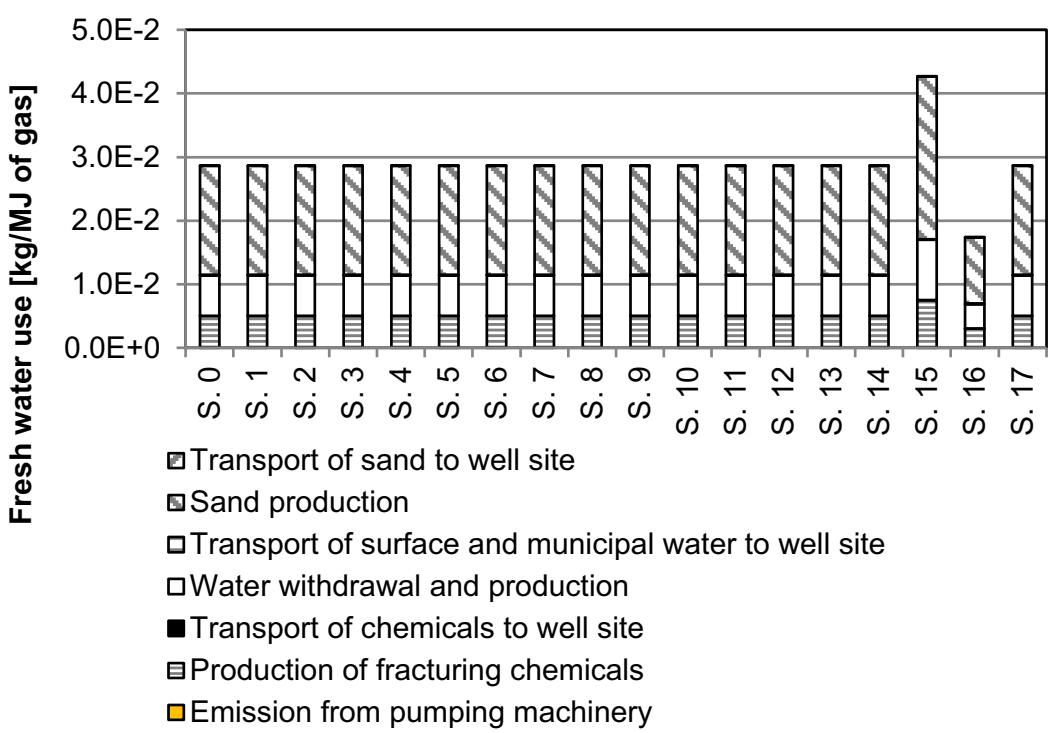


d)

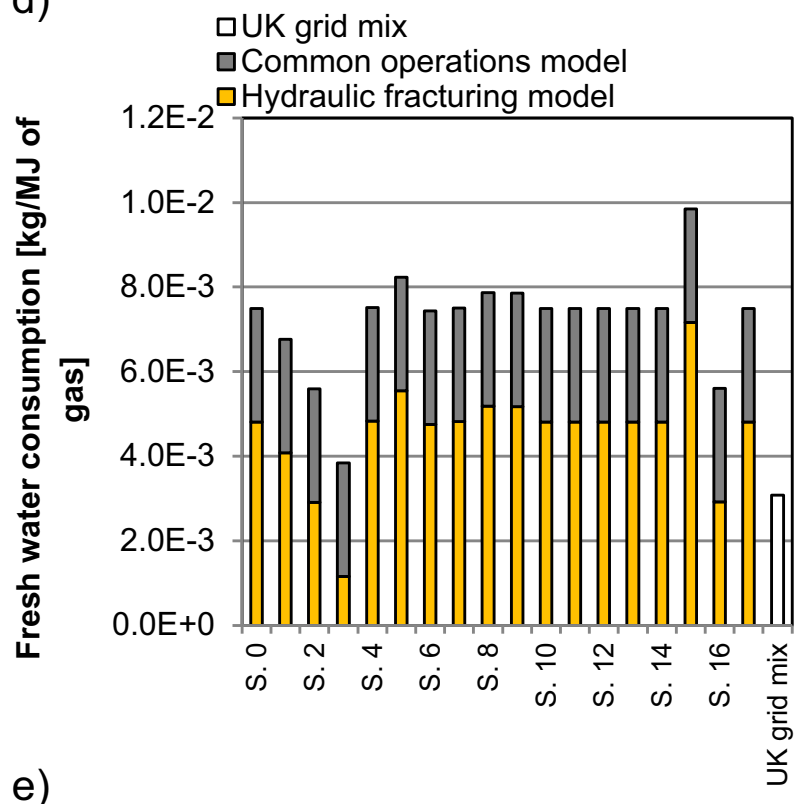

\section{口UK grid mix}

$\square$ Common operations model

口Hydraulic fracturing model

e)

-Emissions

$\square$ Shale fracturing process $\square$ Horizontal drilling

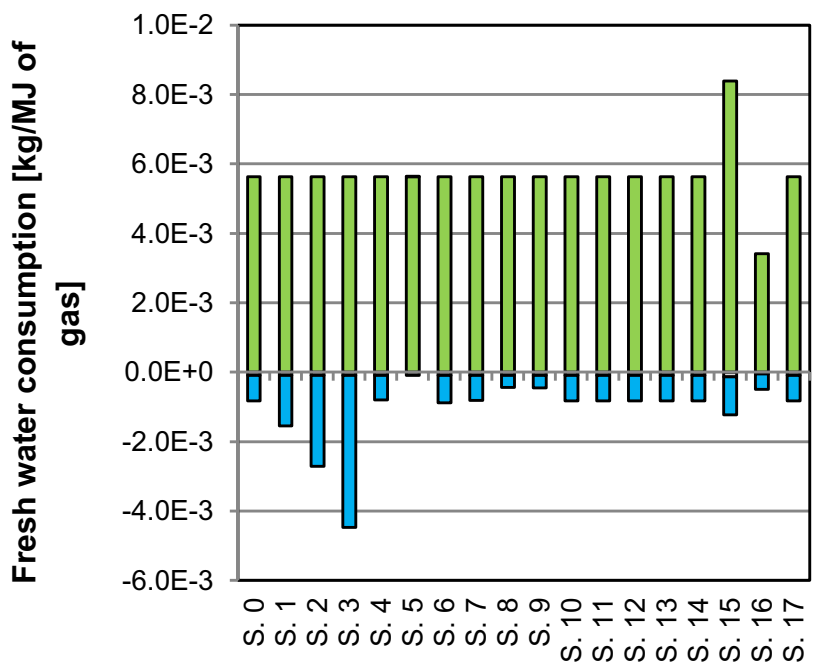

Fig. 2 (continued)

influences the water use of the shale fracturing process except for the EUR. Conversely, the flowback ratio and the flowback handling method influence the water use of the flowback disposal process (as shown for S.1-S.9).

The fracturing process and the flowback disposal are further analysed in Figs. 2c and S2. Figure 2c shows that the excavation and processing of the sand used in the fracturing liquids $(60 \%)$, the withdrawal of fresh water used for cracking the rocks $(23 \%)$ and the production of fracturing chemicals $(17 \%)$ are the main contributors to the water use of the fracturing process. As also reported in Tagliaferri et al. (2015), frac sand must be of uniform size and shape, and to achieve f)

口UK grid mix

口Common operations model

口Hydraulic fracturing model

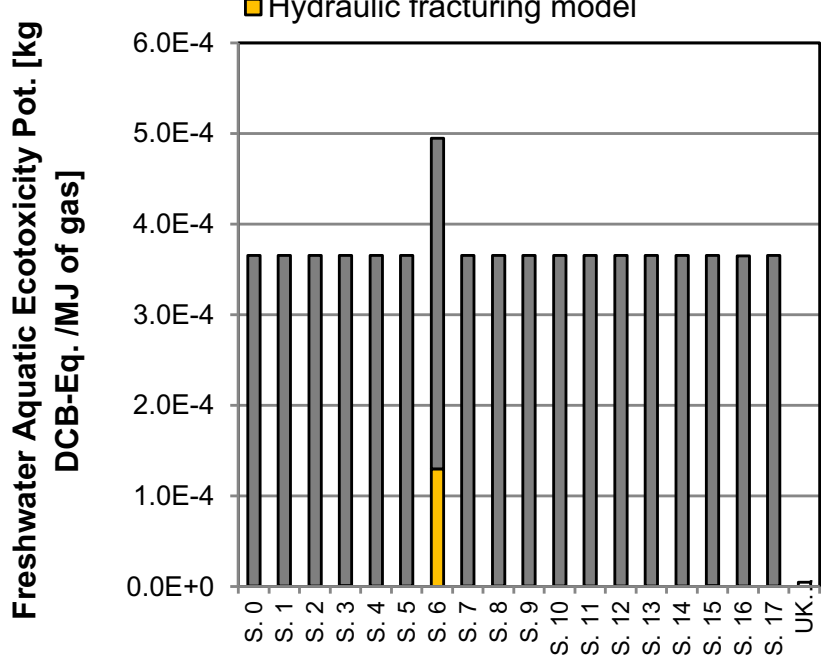

g)

\section{口Low pressure distribution at consumer \\ - High pressure distribution at consumer 口Long distance distribution}
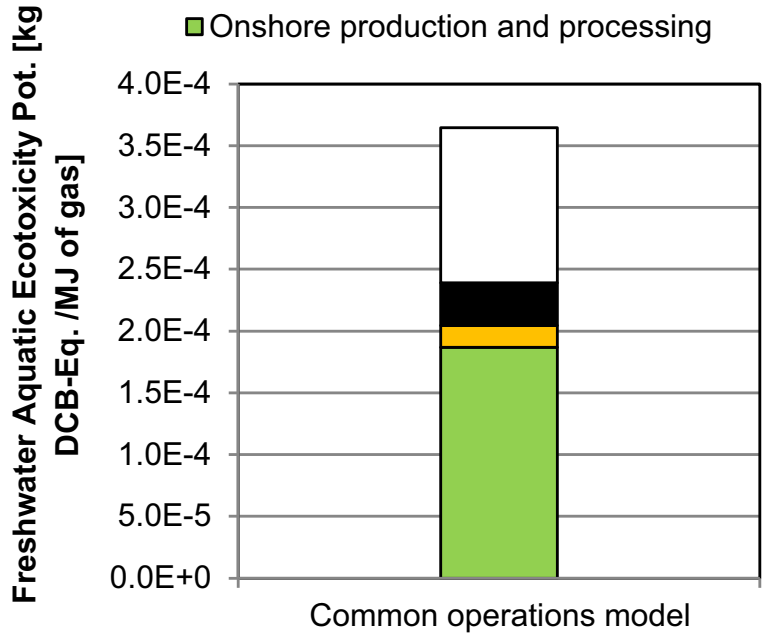

this, a deep processing is needed (Wisconsin Department of Natural Resources 2012). The processing plants wash, dry, sort and store the sand and waste water is produced. This explains the indirect water use associated with the process of sand mining and processing (contributing for $60 \%$ of the total water use of fracturing operations). On the contrary, the water used to produce diesel for transport is negligible.

According to the disposal of flowback fluids, shown in Fig. S2, direct disposal to the environment and disposal to class II wells determine the minimum use of fresh water as no further treatment of waste water is needed (S.5-S.6). S.0-S3 show that increasing the flowback 


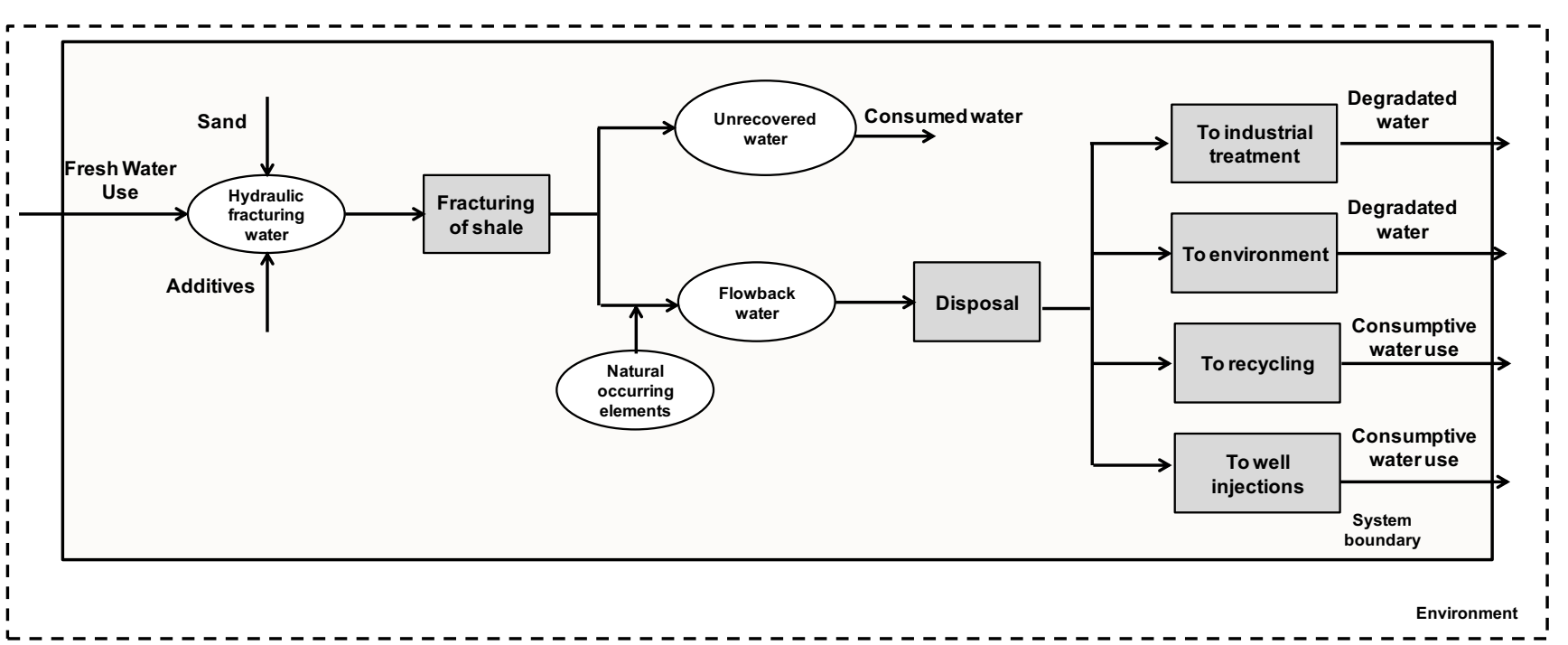

Fig. 3 Life cycle of water when the flowback ratio is lower than $100 \%$

ratio, the water used to treat and dispose of it increase whereas all other scenarios show a constant amount of water used to treat flowback water.

A further analysis on the comparison with the UK grid mix is reported in Sect. 4.

Consumptive water use The hydraulic fracturing model contributes for more than $50 \%$ to the water consumption of the shale gas extraction, except for scenario S.3 (Fig. 2d). Conversely, for S.3, the water consumption is mainly due to the processes included in the common operations model. In this case, the water consumption of the entire hydraulic fracturing model is lower because the amount of water ultimately released to the environment (degradate water) is higher as the flowback ratio is higher than $100 \%$. The EUR is a key parameter for the assessment of the water consumption as it determines a change in the results of $8 \%$ (S.15 and S.16 of Fig. 2d).

Rock fracturing and flowback disposal are the two main contributors to the water consumption as shown in the hotspot analysis of the hydraulic fracturing model (Fig. 2e). The flow back disposal is associated with a net release of lowerquality water to watersheds, and therefore for some scenarios, the water consumption is negative.

As shown in the hot-spot analysis of the shale fracturing process in Fig. 2e, the withdrawal of fresh water contributes for $99 \%$ to the consumption of water and production of sand and chemicals are negligible.

As shown in the flowback disposal hot-spot analysis of Fig. S3, the water consumed to treat the flowback is offset by the degradate water released to the environment for S.0S.3, S.6 and S.9-S.17. S.5 is the only scenario that does not show any negative water consumption in the hot-spot analysis of the hydraulic fracturing model because water is injected into wells, and therefore, it is not released to its withdrawal watershed. For S.4, S.7 and S.8, the negative values of the water consumption are not due to a net release of water to the environment but to the avoided burden allocated to the recycling of flowback.

The EUR and the flowback ratio are again key parameters for the results of the hot-spot analysis of shale gas.

Degradative water use Water degradation represents the difference between water use and consumption, and therefore, it is reported in the Electronic supplementary material.

The degrative effects associated with the water life cycle of shale gas have been quantified using the fresh water aquatic ecotoxicity potential. As shown in Fig. $2 \mathrm{f}$, the fresh water aquatic ecotoxicity of shale gas extraction is mainly associated to the common operations model; the impact of the hydraulic fracturing model is negligible except for scenario 6 where it represents the $26 \%$ of the total burden. The flowback disposal method determines the higher FAETP of S.6 because the flowback is assumed to be completely discharged to rivers without any further treatment. High content of solids, radioactive elements and polluting chemicals determine the FAETP associated with the water discharge. All other disposal methods do not significantly contribute to the FAETP. In the UK, direct discharge of flowback water is not permitted but this analysis assesses the potential impact of illegal disposal or unwanted spills of flowback water. The FAETP of the common operations model is $50 \%$ attributable to onshore gas extraction and processing, and $34 \%$ to the production of pipes used in low pressure distribution network (Fig. 2g). The production of UK natural gas mix causes a significantly lower impact (the FAETP of the UK natural gas grid mix is two orders of magnitude lower than the FAETP of shale gas).

Comparison with UK natural gas grid mix-water impacts The analysis on water life cycle of shale gas has been 
strengthened comparing it with the water use of conventional natural gas currently supplied to the UK. According to Fig. 2a, the UK gas mix model for natural gas causes a higher degradative water use (more than doubles than that of shale gas). The natural gas datasets reported in GaBi database (Thinkstep 2015) show a high variability in the water use results according to the different country specifications. This difference is based on the electricity used during the production phase. The amount of the electricity requirement is not the driver of the water use variability, whereas the different country specific electricity mix determines it. The countries that base their national electricity consumption on hydropower (such as Norway (NO) and France (FR)) show an elevated water use in the results. For the UK natural gas mix, two drivers dominate $75 \%$ of the results: (1) the water use included in the UK electricity grid mix which is used for gas regional distribution and (2) the Norwegian electricity grid mix (identified as a data set with a very high amount of water use) used to produce Norwegian natural gas imported to the UK, on the base of the UK gas import mix. The higher value of the natural gas mix, shown in Fig. 2a, is due to the water use and degradation associated with the UK natural gas imports and in particular to the imports of Norwegian natural gas. Norwegian gas is produced using NO electricity mix that shows a high water degradation due to the hydropower share of the electricity mix. As mentioned above, degradative use takes place when the water used remains in the same watershed but the quality has been altered. Hydropower dams alter water flows and this causes water degradation due to change in water temperature and consequently biological and chemical composition (amount of dissolved oxygen, nutrients and dissolved solid) (Bobat 2015).

Global warming potential The emissions associated only with the fracturing model (the emissions due to completion and workover for conventional extraction are included in the common operations processes) determines between 3 and $12 \%$ of the total GWP of the overall shale gas model (Fig. 4a). The peak value of $12 \%$ is shown for S.11 where the emissions from completion and workovers are assumed to be vented. The use of green devices (S.0) does not seem to significantly improve the GWP of shale gas extraction when compared with the GWP of S.10 where emissions are assumed to be completely flared. It should also be highlighted that the analysis does not include the production and assembly of reduce emission completion (REC) devices as no inventory was available. If the latter were included in the assessment, the use of REC devices may show a different trend in the results. The difference between the GWP of scenario S.10 (where emissions are completely flared) and the GWP of scenario S.12 (where emissions are half flared half captured) is negligible. A change of $\pm 15 \%$ in the amount of emissions does not have a significant impact on the overall results.
As shown in Fig. 4c, except for S.11, the main contributors to the GWP of the hydraulic fracturing model are horizontal drilling (more than $50 \%$ of the GWP of hydraulic fracturing model) and fracturing of shale rocks (around $23 \%$ of the GWP of hydraulic fracturing model). The remaining burdens are due to the emissions associated with completion and workover; for all scenarios, $83 \%$ of those emissions are due to the phase of completion (Fig. 4c).

The amount of diesel used for horizontal drilling is almost two times the amount of diesel used to inject the fracking fluids in the rocks (Stephenson et al. 2011; Burnham et al. 2013). Consequently, direct emissions from machinery during horizontal drilling have a higher environmental impact accounting for $50 \%$ of the total impact of this unit operation. Indirect GWP of horizontal drilling (Fig. S9a) is mainly due to the production of the steel welded pipes for casing the drilling hole (31\% of the total GWP of horizontal drilling) and to the cement production required for drilling mud (17\% of the total GWP of horizontal drilling). Direct emissions from pumping machinery during the hydraulic fracturing also determine the main GWP contribution to the fracturing process (Fig. S9b). Slips of gas from onshore gas production and processing and from distribution determine the GWP of the common operations model reported in Fig. 4b.

The values found for the GWP are in line with the range reported by other authors (Burnham et al. 2011; Jiang et al. 2011). The difference between shale gas and UK grid mix gas is due to lower emissions during the offshore extraction activities and different EUR.

However, it is worth pointing out that the GWP reported in this work does not include unwanted slippage of methane through the well casing. It is assumed that the well has been properly installed, and therefore, no gas escapes through a faulty casing into shallow aquifers and then into the atmosphere (the evidence of this faulty possibility is reported in (Osborn et al. 2011)). Usually to prevent leaks, during well installation, cement is pumped into the space between the pipes and the surrounding rocks but if the cement has gaps, gas can bubble up. The frequency of well construction problems in the USA is reported to be between 3.4 and $6 \%$ according to different researchers (Stokstad 2014). If shale gas extraction develops in the UK, it is assumed that the casing should be properly installed and checked and therefore the frequency of well construction problems should be lower than that reported in the USA; for this reason in this analysis, we have not taken into account unwanted fugitive methane from well casing.

Abiotic depletion potential The model of hydraulic fracturing determines a negligible abiotic depletion potential (ADP fossil) when compared with the common operations model, (Fig. S6a) because the main depletion of fossil resources is 
Fig. 4 Global warming. Potential of shale gas production and distribution. a Shale gas overall model. b Common operations model. c Hydraulic fracturing model. The results are reported for the delivery of $1 \mathrm{MJ}$ LHV of natural gas to the final consumer

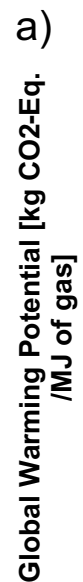

口UK grid mix

口Common operations model

口Hydraulic fracturing model

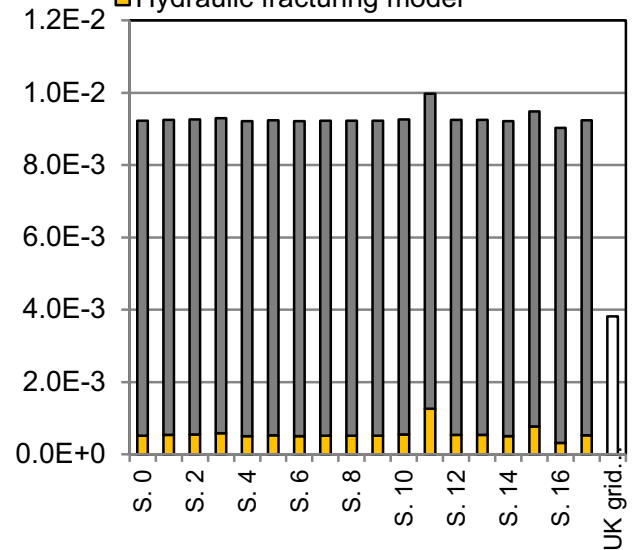

b) aLow pressure distribution at consumer

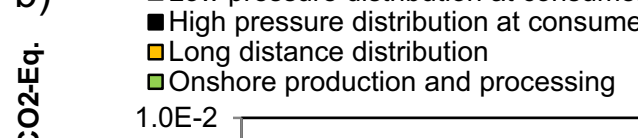

g) $9.0 \mathrm{E}-3$

量嵒

8.0E-3

$7.0 \mathrm{E}-3$

$6.0 \mathrm{E}-3$

5.0E-3

$4.0 \mathrm{E}-3$

$3.0 \mathrm{E}-3$

$2.0 \mathrm{E}-3$

$1.0 \mathrm{E}-3$

$0.0 \mathrm{E}+0$

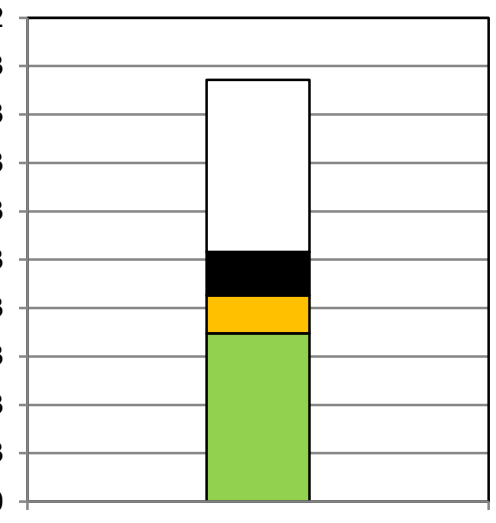

Common operations model

c)

$\square$ Horizontal drilling $\square$ Shale fracturing process $\square$ Flowback disposal $\boldsymbol{\square}$ Emissions
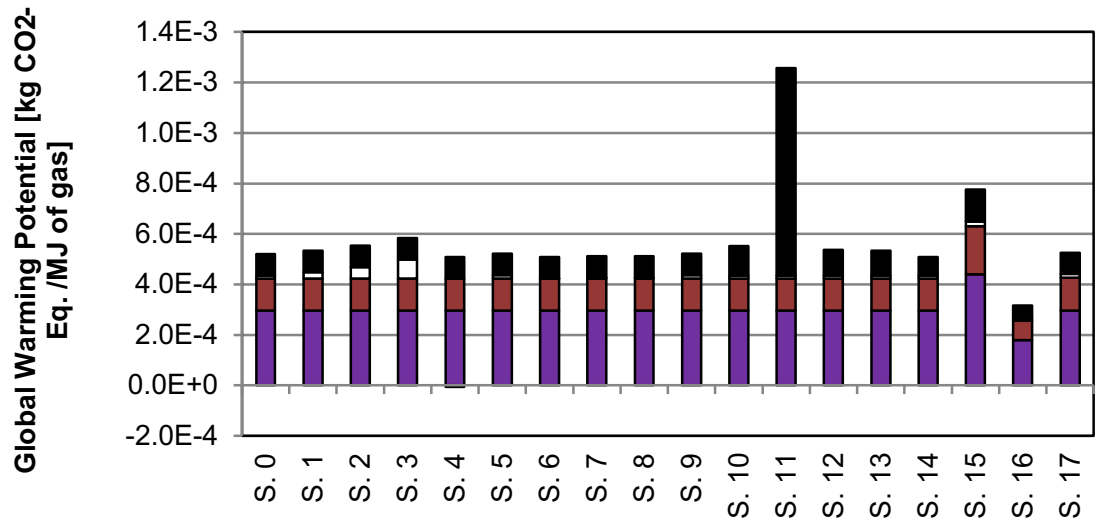

due to gas exploitation (Fig. S6b). The ADP fossil associated with the hydraulic fracturing model is two orders of magnitude lower than that associated with the common operations model. No sensible variation is shown for the different parameters; the ADP fossil of shale gas is comparable with the ADP fossil of conventional UK grid mix supply as also already reported in (Stamford and Azapagic 2014).

Acidification potential The burden of the hydraulic fracturing model represents between 1.5 and $5 \%$ of the total 
environmental burden of overall shale gas model (Fig. S7a). More than $90 \%$ of the acidification potential (AP) is due again to the conventional extraction of the common operations model, specifically to emissions due to drilling, leakage and processing (Fig. S7b); no sensible variation is shown for the different parameters. Shale gas is likely to have an impact about seven times higher than the impact of UK conventional gas mix because of lower emissions during the offshore extraction phase (Thinkstep 2015) and higher EUR (Fig. S7a).

Eutrophication potential The hydraulic fracturing model significantly contribute to the total burden of overall shale gas model (between 9 and $20 \%$ of the total eutrophication potential (EP) of the shale gas model is due to the hydraulic fracturing model, see Fig. S8a). The major variability of the results is seen in S.15 and S.16 according to a change in EUR. Fifty-seven percent $(57 \%)$ of the EP of the common operations model is due to the emissions associated with the production phase; $20 \%$ of the EP of the common operations model is due to the low-pressure distribution by pipes (pipe construction is the process that mainly contributes to the distribution process) (see Fig. S8b). The hot-spot analysis of the hydraulic fracturing model (see Fig. S8c) shows that the horizontal drilling is the main contributor this process contributing for more than $50 \%$ of the total $(93 \%$ of which is due to direct emissions from drilling machinery). Furthermore, the direct emissions from pumping machinery contribute $90 \%$ to the burden of the fracturing process. In S.6, the increased EP of the hydraulic fracturing model (due to the flowback disposal operations) is due to the direct discharge of waste water to rivers. The comparison with conventional UK grid mix shows similar results to AP.

Human toxicity potential As shown in Fig. S10a, the hydraulic fracturing model constantly determines $4.5 \%$ of the human toxicity potential (HTP) of the overall shale gas model except for S.6 (40 \%), S.15 (6\%) and S.16 (2.5\%); the EUR does not significantly influence the results. As already reported for the FAETP, the increased toxicity of S6 is due to the assumption of flowback discharge to rivers (Fig. S10c). The HTP associated with the common operations model is due to pipeline production for low pressure distribution (49\%) and to onshore well drilling and gas production (35\%) as shown in Fig. S10b. Conventional gas shows a lower HTP than shale gas.

Ozone layer depletion potential The ozone layer depletion potential (ODP) of the hydraulic fracturing model is negligible when compared with the ODP of the overall shale gas model (Fig. S11a). The main contribution is due to the common operations model and in particular to the pipe construction for long distance and high-pressure transport (Fig. S11b). No sensible variation is shown for the different parameters.
Photochemical ozone creation potential (POCP) The photochemical ozone creation potential (POCP) of the hydraulic fracturing model is negligible as well (Fig. S11c), but in this case, the POCP of S.11 reaches $4 \%$ of the total POCP of the overall shale gas model. Emissions of higher hydrocarbons to the atmosphere $\left(\mathrm{C}_{2} \mathrm{H}_{6}\right.$ and $\mathrm{C}_{3} \mathrm{H}_{8}$ constituting part of the natural gas) increase the POCP value of the common operations model and of the hydraulic fracturing model in the case of S.11 (Fig. S11c, d). The UK grid mix gas shows lower ODP and POCP compared with shale gas, and this is due to lower emissions during the offshore extraction activities and lower EUR.

Terrestric ecotoxicity potential The hydraulic fracturing model determines the $2-3 \%$ of the total terrestric ecotoxicity potential (TETP) of the overall shale gas model (Fig. S12a). Onshore drilling, extraction and processing are the main contributors to the common operations model (Fig. S12b). The UK gas grid mix shows a lower TETP compared with shale gas (Fig. S12a).

Overall, for all the indicators analysed, transport of water, chemicals and sand does not show any strong impact on the total environmental burden of shale gas extraction as scenario 17 does not significantly change the trend of the results. Also, the production of chemicals does not strongly influence the results.

\section{Discussion}

This discussion analyses the most critical operations of shale gas production, particularly looking at the water life cycle and shows the comparison of the results presented in this study with the results reported in literature.

The previous analysis has shown that the flowback ratio and the flowback handling method are key elements for the water use results. Hence, this aspect is further discussed according to Fig. 3 that reports the life cycle of water when the flowback ratio is lower than $100 \%$. Each of the disposal methods previously analysed-(i) disposal to class II wells, (ii) direct disposal to fresh water, (iii) recycling and (iv) disposal to industrial facilities - can determine either a consumptive or degradative use of water.

1. Disposal through well injection always determines a consumptive use of water (independently from the flowback ratio) as the fresh water withdrawn from environment before hydraulic fracturing is not released again to watersheds.

2. The direct disposal of flowback to rivers might determine either a degradative use or a consumptive use of water depending on the flowback ratio. If the flowback ratio is lower than $100 \%$, then the direct disposal to rivers and 
lakes always determines a consumptive use of water. In this case, the amount of water withdrawn from environment prior to hydraulic fracturing is not completely consumed; part of it is released again to rivers but in a lower grade (degradative use of water) during flowback disposal. When the flowback ratio is higher than $100 \%$, then the use of water is not consumptive but only degradative.

3. For disposal to proper industrial treatment, the same comments as direct disposal to environment apply.

4. Conversely, for flowback recycling, the use of water is consumptive when the flowback ratio is lower than $100 \%$. In this case, the amount of water consumed is decreased by the amount of fresh water that is not withdrawn to hydraulically fracture another well thanks to water recycling.

A summary of the overall results are reported in Table 3.

Spillage of flowback water can negatively affect the toxicity indicators because of the composition of this water. However, if sensible solutions of flow disposal are adopted, the operations associated with the hydraulic fracturing have been shown not to substantially increase the environmental burdens of the operations that are the same between shale gas and conventional natural gas extraction, as quantified by the indicators of the CML methodology.

Nevertheless, the production and distribution of the UK natural gas mix determines lower impacts for almost all the indicators. The current UK gas supply mainly comes from offshore resources, and production rates for offshore wells tend to be high. This is because the natural gas reservoir must be large enough to justify the capital outlay for the completion of a well and the construction of an offshore drilling platform (Skone et al. 2014). Therefore, higher productivity of offshore wells than shale gas wells $\left(9.4 * 10^{8} \mathrm{~m}^{3}\right.$ for UK offshore wells (Thinkstep 2015) and $10^{7} \mathrm{~m}^{3}$ of gas for shale wells) determine lower environmental impacts.

Furthermore, shale gas production does strongly impact the water resource use when compared with the conventional production - this also depends on the electricity mix used to fulfil the energy requirements of the production processes, as shown, for example for the natural gas imported from Norway.

The results shown for S.0 were compared with the results of the "central case" reported in Cooper et al. (2014) and Stamford and Azapagic (2014). We considered the functional

Table 3 Summary of the results

\begin{tabular}{|c|c|c|c|}
\hline & \multicolumn{2}{|c|}{$\begin{array}{l}\text { Hot spot analysis of the } \\
\text { shale gas production } \\
\text { process }\end{array}$} & \multirow{2}{*}{$\begin{array}{l}\text { Comparison of shale gas production with } \\
\text { the production of the UK natural gas grid } \\
\text { mix } \\
\text { (shale gas-conventional } \\
\text { gas)/conventional gas }\end{array}$} \\
\hline & $\begin{array}{l}\text { Common } \\
\text { operations }\end{array}$ & $\begin{array}{l}\text { Hydraulic } \\
\text { fracturing }\end{array}$ & \\
\hline $\begin{array}{l}\text { Abiotic Depletion } \\
{[\%]}\end{array}$ & $9.94 \mathrm{E}+01$ & $5.85 \mathrm{E}-01$ & $-3.91 \mathrm{E}+00$ \\
\hline $\begin{array}{l}\text { Acidification } \\
\text { Potential [\%] }\end{array}$ & $9.75 \mathrm{E}+01$ & $2.50 \mathrm{E}+00$ & $6.32 \mathrm{E}+02$ \\
\hline $\begin{array}{l}\text { Eutrophication } \\
\text { Potential [\%] }\end{array}$ & $8.55 \mathrm{E}+01$ & $1.45 \mathrm{E}+01$ & $1.62 \mathrm{E}+02$ \\
\hline $\begin{array}{l}\text { Freshwater Aquatic } \\
\text { Ecotoxicity Pot. } \\
{[\%]}\end{array}$ & $9.98 \mathrm{E}+01$ & $1.55 \mathrm{E}-01$ & $1.82 \mathrm{E}+02$ \\
\hline $\begin{array}{l}\text { Global Warming } \\
\text { Potential [\%] }\end{array}$ & $9.44 \mathrm{E}+01$ & $5.64 \mathrm{E}+00$ & $1.31 \mathrm{E}+02$ \\
\hline $\begin{array}{l}\text { Human Toxicity } \\
\text { Potential [\%] }\end{array}$ & $9.59 \mathrm{E}+01$ & $4.14 \mathrm{E}+00$ & $7.50 \mathrm{E}+01$ \\
\hline $\begin{array}{l}\text { Ozone Layer } \\
\text { Depletion Potential } \\
{[\%]}\end{array}$ & $9.99 \mathrm{E}+01$ & 1.34E-01 & $2.27 \mathrm{E}+04$ \\
\hline $\begin{array}{l}\text { Photochem. Ozone } \\
\text { Creation Potential } \\
{[\%]}\end{array}$ & $9.90 \mathrm{E}+01$ & $9.59 \mathrm{E}-01$ & $8.08 \mathrm{E}+02$ \\
\hline $\begin{array}{l}\text { Terrestric } \\
\text { Ecotoxicity } \\
\text { Potential }[\%] \\
\end{array}$ & $9.78 \mathrm{E}+01$ & $2.24 \mathrm{E}+00$ & $2.10 \mathrm{E}+02$ \\
\hline Water use [\%] & $7.92 \mathrm{E}+00$ & $9.21 \mathrm{E}+01$ & $-6.01 E+01$ \\
\hline $\begin{array}{l}\text { Water consumption } \\
{[\%]}\end{array}$ & $3.58 \mathrm{E}+01$ & $6.42 \mathrm{E}+01$ & $1.43 \mathrm{E}+02$ \\
\hline $\begin{array}{l}\text { Water degradation } \\
{[\%]}\end{array}$ & $0.00 \mathrm{E}+00$ & $1.00 \mathrm{E}+02$ & $-6.78 \mathrm{E}+01$ \\
\hline
\end{tabular}

For each environmental indicator, the table indicates which are the operations that mainly contribute to the environmental impact of shale gas production. Hydraulic fracturing includes horizontal drilling, shale rock fracturing, flowback disposal and emissions associated to hydraulic fracturing whereas the common operations refers to gas field exploration, natural gas production, purification, long distance transport and regional distribution (operations of conventional gas extraction common also to shale gas extraction). In the last two columns, the table summaries whether shale gas or the UK grid mix causes the highest environmental impacts. Red represents higher values, and green represents lower values 
unit of $1 \mathrm{MJ}$ of gas delivered to the final consumer for the three studies and excluded the use phase. Figure 5a shows the variations obtained between our results and the literature and also directly compares the results of the two previous studies. A good agreement among all three studies is shown for the
ADP fossil, the AP, the GWP, the ODP and the POCP. In particular, a variation of less than $5 \%$ is shown for the GWP. However, the results regarding the toxicity impacts and the EP, significantly differ from the values reported in previous studies. This can be explained looking at two factors.
Fig. 5 Comparison with literature. a The results of S.0 are compared with the normal cases of Cooper et al. (2014) and Stamford and Azapagic (2014); b the results of S.0 are compared with the best cases of Cooper et al. (2014) and Stamford and Azapagic (2014) a)

(Central case of Cooper et al - Central case of Stamford et al. $) /($ Central case of Cooper et al.)

- (Central case of Stamford et al - This study S.0)/This study S.0

- (Central case of Cooper et al - This study S.0)/This Study S.0

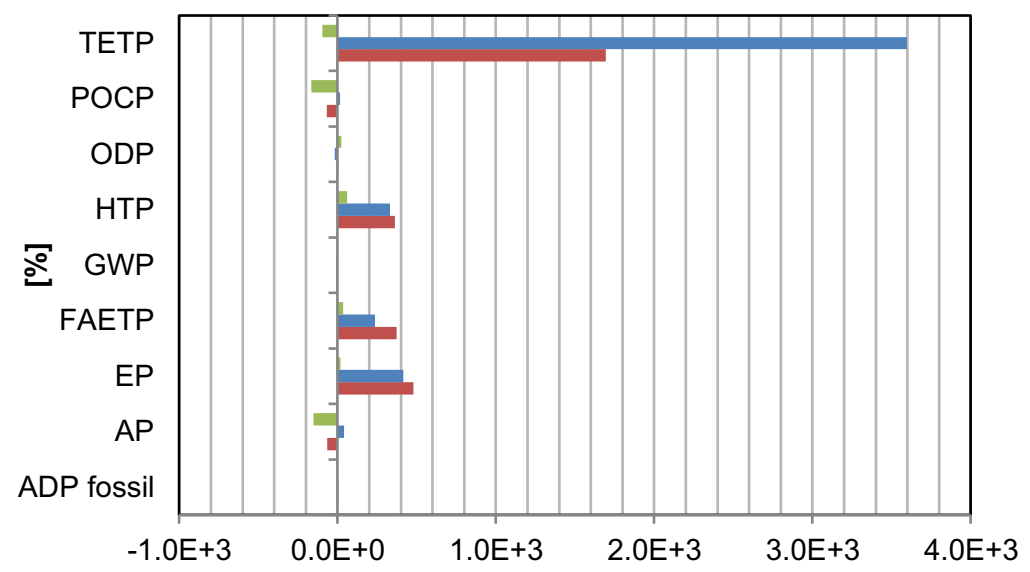

b)

(Best case of Cooper et al - Best case of Stamford et al.)/(Best case of Cooper et al.)

" (Best case of Stamford et al - This study S.0)/This study S.0

- (Best case of Cooper et al - This study S.0)/This Study S.0

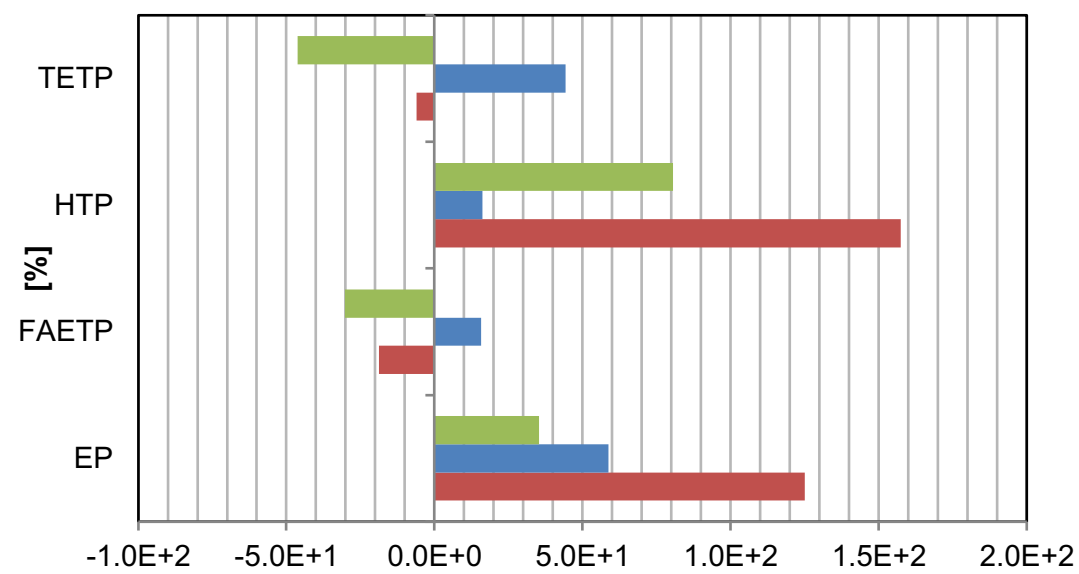


(i) Cooper et al. (2014) and Stamford and Azapagic (2014) already showed a significant variation in their results for these impacts when comparing worst, central and best case scenarios. Therefore, we compared the toxicities and the EP of S.0 with the best cases of Cooper et al. (2014) and Stamford and Azapagic (2014) (see Fig. 5b). A lower variation is shown.

(ii) The HTP, FAETP and TETP are the least robust impact categories and this could affect the results.

Overall, our study confirms the central case results obtained in literature for the ADP fossil, the AP, the GWP, the ODP and the POCP; whereas the best case scenarios are confirmed for the remaining impact categories.

\section{Conclusions}

The promising development that shale gas had in the USA has catalysed interest in shale gas also in other countries worldwide. In Europe, shale is still in its early development stage and, for example in the UK, exploration and trials of UK shale gas reserves have just started but commercial production has not begun yet. This work analysed the environmental impacts of UK shale gas exploration, production and transmission at low pressure to the consumer. A sensitivity analysis was performed on EUR, fraction of flowback, emission handling methods and amount of emissions, flowback disposal method and transport distance. Particular focus was put on the water impacts; water use, water degradation and water consumption were explored and environmental impacts, including acidification potential, abiotic depletion fossil, toxicities etc. were also considered, hence providing a further reference point against previous works.

The water impacts of shale gas significantly depend on the procedures adopted during gas production. Direct disposal of the waste water, produced during the fracking operations, to fresh water is banned by law in the UK. This work analysed what are the possible threats of unwanted spills of flowback water when compared with the environmental impacts of conventional gas supply to the UK. Improper waste water management substantially increases all the toxicity impacts. This means that water and human life can be exposed to unnecessary threats, even double those caused by industrial waste water treatment.

The water degradation of the conventional natural gas supply to the UK was shown to be even higher than that of shale gas. Conversely, the water used for the shale fracturing process significantly increases the water consumption when compared to the water consumption of the UK gas mix. Hence, political investment should support the recycling of flowback water as this solution allows a reduction of the total water consumption associated with shale gas production. In particular, advanced researches to improve the efficiency of the recycling process should be strongly taken into consideration.

The EUR of the well was shown to have the greatest impact on the results as well as flowback ratio and flowback disposal method. This is explained knowing that the energy and materials used for one well are the same whether the well is going to have a high or low productivity. Therefore, the impacts associated with a low productive well are higher. This is valid also for the comparison between shale gas and UK grid mix gas; currently, the UK gas supply mainly comes from offshore platforms and a higher productivity of offshore wells (compared with onshore wells and shale gas) determine the higher environmental impact of shale gas. The environmental impacts of shale gas should mainly be considered according to the low productivity of shale wells that force the drilling and exploitation of a high number of wells. This is the drive of higher environmental impacts.

The emissions from drilling and pumping machineries associated with the operations specifically required for hydraulic fracturing significantly contributes to the total EP of the shale gas production. Conversely, the operations involved in hydraulic fracturing have shown a minor impact on the ADP fossil, AP ODP, TETP and POCP. For the GWP, the handling methods of the emissions associated with the hydraulic fracturing influence the results only when emissions are vented.

The results of this study were compared with the results of previous studies, and a good agreement was shown.

The analysis is limited by the early development of the shale gas exploitation in the EU. Available data are usually scarce and not robust. Further development and trials of UK shale gas extraction together with field data publicly released may help to overcome this limitation in the future.

Acknowledgements The authors acknowledge Prof. Alberto Striolo for useful discussions. This project has received funding from the European Union's Horizon 2020 research and innovation programme under grant agreement no. 640979 .

Open Access This article is distributed under the terms of the Creative Commons Attribution 4.0 International License (http:// creativecommons.org/licenses/by/4.0/), which permits unrestricted use, distribution, and reproduction in any medium, provided you give appropriate credit to the original author(s) and the source, provide a link to the Creative Commons license, and indicate if changes were made.

\section{References}

Allen DT, Pacsi AP, Sullivan DW et al (2015a) Methane emissions from process equipment at natural gas production sites in the United States: pneumatic controllers. Environ Sci Technol 49:633-640

Allen DT, Sullivan DW, Zavala-Araiza D et al (2015b) Methane emissions from process equipment at natural gas production sites in the United States: liquid unloadings. Environ Sci Technol 49:641-648 
Amann-Hildenbrand A, Ghanizadeh A, Krooss BM (2012) Transport properties of unconventional gas systems. Mar Pet Geol 31:90-99

Bobat A (2015) Energy systems and management. Springer Proceedings in Energy. doi:10.1007/978-3-319-16024-5 2

Boersma T (2013) Four questions on shale gas development in Europe and the U.S. http://www.brookings.edu/research/opinions/2013/11/ 15-shale-gas-oil-boom-europe-boersma. Accessed 13 May 2016

Boschee P (2014) Produced and flowback water recycling and reuse economics, limitations, and technology

Broadhead R (2012) Petroleum geology: an introduction

Broderick J, Anderson PK, Wood R et al (2011) Shale gas: an updated assessment of environmental and climate change impacts. Report commissioned by the co-operative and undertaken by researchers at the Tyndall Centre. University of Manchester, Manchester

Burnham A, Han J, Clark CE et al (2011) Life-cycle greenhouse gas emissions of shale gas, natural gas, coal, and petroleum. Environ Sci Technol 46:619-627

Burnham A, Han J, Elgowainy A, Wang M (2013) Updated fugitive greenhouse gas emissions for natural gas pathways in the GREET TM model. Systems Assessment Group Energy Systems Division, Argonne National Laboratory, Lemont

Cathles L, Brown L, Taam M, Hunter A (2012) A commentary on "the greenhouse-gas footprint of natural gas in shale formations. Clim Chang 113:525-535

Chang Y, Huang R, Ries RJ, Masanet E (2014) Shale-to-well energy use and air pollutant emissions of shale gas production in China. Appl Energy 125:147-157

Chang Y, Huang R, Ries RJ, Masanet E (2015) Life-cycle comparison of greenhouse gas emissions and water consumption for coal and shale gas fired power generation in China. Energy 86:335-343

Clark CE, Han J, Burnham A et al (2011) Life-cycle analysis of shale gas and natural gas. Argonne National Laboratory, Lemont

Clark CE, Burnham A, Horner RM (2013a) Hydraulic fracturing and shale gas production: technology, impacts, and regulations. Argonne National Laboratory, Lemont

Clark CE, Horner RM, Harto CB (2013b) Life cycle water consumption for shale gas and conventional natural gas. Supporting information. Environ Sci Technol 47(20):11829-11836

Clark CE, Horner RM, Harto CB (2013c) Life cycle water consumption for shale gas and conventional natural gas. Environ Sci Technol 47: $11829-11836$

Cooper J, Stamford L, Azapagic A (2014) Environmental impacts of shale gas in the UK: current situation and future scenarios. Energy Technol 2:1012-1026

Cuadrilla (2016) Fracturing Fluid | Cuadrilla Resources. http://www. cuadrillaresources.com/what-we-do/hydraulic-fracturing/fracturingfluid/. Accessed 8 Mar 2016

Dale AT, Khanna V, Vidic RD, Bilec MM (2013) Process based life-cycle assessment of natural gas from the Marcellus shale. Environ Sci Technol 47:5459-5466

DECC (2013a) Shale gas background note

DECC (2013b) Potential greenhouse gas emissions associated with shale gas extraction and use

EIA U (2013) Technically recoverable shale oil and shale gas resources: an assessment of 137 shale formations in 41 countries outside the United States

Forster D, Perks J (2012) Climate impact of potential shale gas production in the EU Final Report

Guinée JB (2002) Handbook on life cycle assessment, operational guide to the ISO Standards, Kluwer Aca

GWPC and ALL Consulting (2009) Modern shale gas development in the United States: a primer

Howarth B, Santoro R, Ingraffea T (2011a) Developing natural Gas in the Marcellus and other shale formations is likely to aggravate global warming. Cornell University, Ithaca
Howarth RW, Santoro R, Ingraffea A (2011b) Methane and the greenhouse-gas footprint of natural gas from shale formations. Clim Chang 106:679-690

Howarth RW, Drew S, Santoro R et al (2012a) Methane emissions from natural gas systems. Background paper prepared for the National Climate Assessment Reference number 2011-0003, pp 1-8

Howarth RW, Santoro R, Ingraffea A (2012b) Venting and leaking of methane from shale gas development: response to Cathles et al. supplemental information

Hultman N, Rebois D, Scholten M, Ramig C (2011) The greenhouse impact of unconventional gas for electricity generation. Environ Res Lett 6:049504

ISO 14040 (2006) International standard. In: Environmental management - life cycle assessment - principles and framework

ISO 14046 (2014) Water footprint-principles, requirements and guidelines

Jackson RB, Lowry ER, Pickle A et al (2015) The depths of hydraulic fracturing and accompanying water use across the United States. Environ Sci Technol 49:8969-8976

Jiang M, Michael Griffin W, Hendrickson C et al (2011) Life cycle greenhouse gas emissions of Marcellus shale gas. Environ Res Lett 6: 034014

Jiang M, Hendrickson CT, VanBriesen JM (2014) Life cycle water consumption and wastewater generation impacts of a Marcellus shale gas well. Environ Sci Technol 48:1911-1920

Kang M, Kanno CM, Reid MC et al (2014) Direct measurements of methane emissions from abandoned oil and gas wells in Pennsylvania. Proc Natl Acad Sci 111:201408315

Kounina A, Margni M, Bayart J-B et al (2012) Review of methods addressing freshwater use in life cycle inventory and impact assessment. Int J Life Cycle Assess 18:707-721

Laurenzi IJ, Jersey GR (2013) Life cycle greenhouse gas emissions and freshwater consumption of Marcellus shale gas. Environ Sci Technol 47:4896-4903

Lechtenbohmer S, Altamann M, Capito S et al (2011) Impacts of shale gas and shale oil extraction on the environment and on human health. European Parliament

Maguire-Boyle SJ, Barron AR (2014) Organic compounds in produced waters from shale gas wells. Environ Sci Process Impacts 16:2237-2248

Newell RG, Raimi D (2014) Implications of shale gas development for climate change. Environ Sci Technol 48:8360-8368

O'Sullivan F (2012) Shale gas production potential versus actual greenhouse gas emissions. Suppl info. Environ Res Lett 21-46

O'Sullivan F, Paltsev S (2012) Shale gas production: potential versus actual greenhouse gas emissions. Environ Res Lett 7:044030

Oil \& gas (2013) A slow costly road to nowhere: shale gas development in Europe

Osborn SG, Vengosh A, Warner NR, Jackson RB (2011) Methane contamination of drinking water accompanying gas-well drilling and hydraulic fracturing. Proc Natl Acad Sci U S A 108:8172-8176

Pacsi AP, Alhajeri NS, Zavala-araiza D et al (2013) Regional air quality impacts of increased natural gas production and use in Texas. Environ Res Lett 47:3521-3527

Peduzzi P, Harding R (2013) Gas fracking : can we safely squeeze the rocks? Environ Dev 6:86-99

Rozell DJ, Reaven SJ (2012) Water pollution risk associated with natural gas extraction from the Marcellus shale. Risk Anal 32:1382-1393

Shale gas Europe (2014) Shale gas explained. http://shalegas-europe. eu/shale-gas-explained/shale-gas-and-europe/. Accessed 13 May 2016

Skea J (2015) A guide to shale gas. Energy Institute

Skone T, Lettlefield J, Marriott J (2011) Life cycle greenhouse gas inventory of natural gas extraction, delivery and electricity production. US Department of Energy, National Energy Technology Laboratory, Morgantown 
Skone T, Littlefield J, Marriott J et al (2014) Life cycle analysis of natural gas extraction and power generation. US Department of Energy, National Energy Technology Laboratory, Morgantown

Speight JG (2009) Shale gas production processes, Kindle Edi. Gulf Professional

Stamford L, Azapagic A (2014) Life cycle environmental impacts of UK shale gas. Appl Energy 134:506-518

Stephenson E, Shaw K (2013) A dilemma of abundance: governance challenges of reconciling shale gas development and climate change mitigation. Sustainability 5:2210-2232

Stephenson T, Valle JE, Riera-palou X et al (2011) Modeling the relative GHG emissions of conventional and shale gas production. Environ Sci Technol 45:10757-10764

Stokstad BE (2014) Will fracking put too much fizz in your water? Science 344(6191):1468-1471

Swiss Centre for Life Cycle Inventories (2014) Ecoinvent: the life cycle inventory data, version 3.0. Swiss Centre for Life Cycle Inventories, Duebendorf

Tagliaferri C, Lettieri P, Chapman C (2015) Life cycle assessment of shale gas in the UK. Energy Procedia 75:2706-2712
The museum of earth (2012) Understanding drilling technology

Thinkstep (2015) GaBi 6 software-system and databases for life cycle engineering. Stuttgart, Echterdingen (see www.peeurope.com)

Vengosh A, Jackson RB, Warner N et al (2014) A critical review of the risks to water resources from unconventional shale gas development and hydraulic fracturing in the United States. Environ Sci Technol 48:8334-8348

Wang Z, Krupnick A (2013) A retrospective review of shale gas development in the United States: what led to the boom? SSRN Electron J. doi:10.2139/ssrn.2286239

Weber CL, Clavin C (2012) Life cycle carbon footprint of shale gas: review of evidence and implications. Environ Sci Technol 46: $5688-5695$

Wisconsin Department of Natural Resources (2012) Silica sand mining in Wisconsin

Wood R, Gilbert P, Sharmina M et al (2011) Shale gas: a provisional assessment of climate change and environmental impacts Tyndall Centre Manchester Shale gas: a provisional assessment of climate change and environmental impacts 